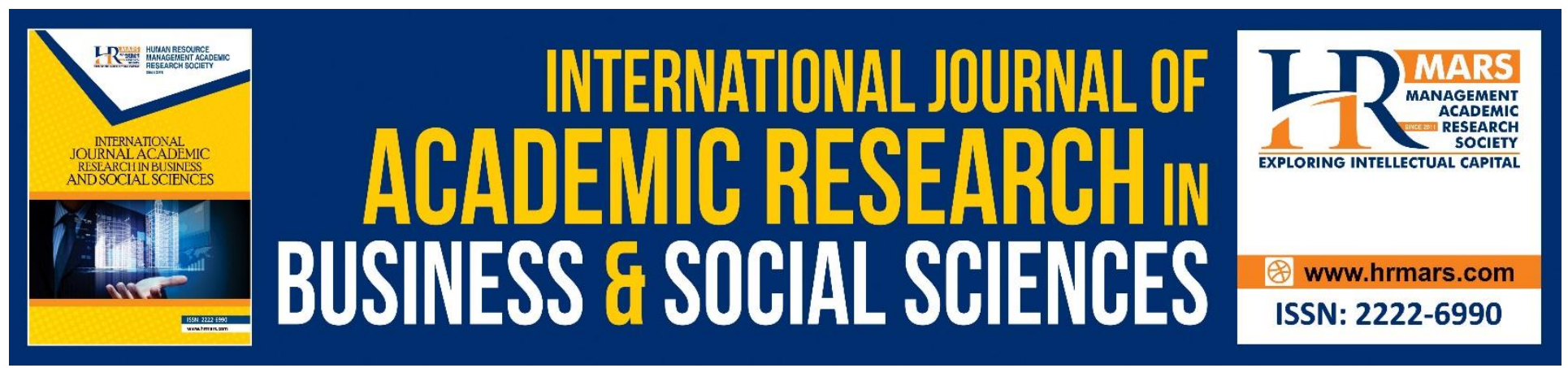

\title{
Experts' View within Fatwa Production in Malaysia
}

\section{Wan Mohd Khairul Firdaus Wan Khairuldin, Wan Nur Izzati Wan Nor Anas, Abdul Hanis Embong}

To Link this Article: http://dx.doi.org/10.6007/IJARBSS/v8-i11/4927

DOI: $10.6007 /$ IJARBSS/v8-i11/4927

Received: 26 Oct 2018, Revised: 21 Nov 2018, Accepted: 30 Nov 2018

Published Online: 05 Dec 2018

In-Text Citation: (Khairuldin, Anas, \& Embong, 2018)

To Cite this Article: Khairuldin, W. M. K. F. W., Anas, W. N. I. W. N., \& Embong, A. H. (2018). Experts' View within Fatwa Production in Malaysia. International Journal of Academic Research in Business and Social Sciences, 8(11), 530-538.

\section{Copyright: (c) 2018 The Author(s)}

Published by Human Resource Management Academic Research Society (www.hrmars.com)

This article is published under the Creative Commons Attribution (CC BY 4.0) license. Anyone may reproduce, distribute, translate and create derivative works of this article (for both commercial and non-commercial purposes), subject to full attribution to the original publication and authors. The full terms of this license may be seen

at: http://creativecommons.org/licences/by/4.0/legalcode

Vol. 8, No. 11, 2018, Pg. 530 - 538

http://hrmars.com/index.php/pages/detail/IJARBSS

JOURNAL HOMEPAGE

Full Terms \& Conditions of access and use can be found at http://hrmars.com/index.php/pages/detail/publication-ethics 


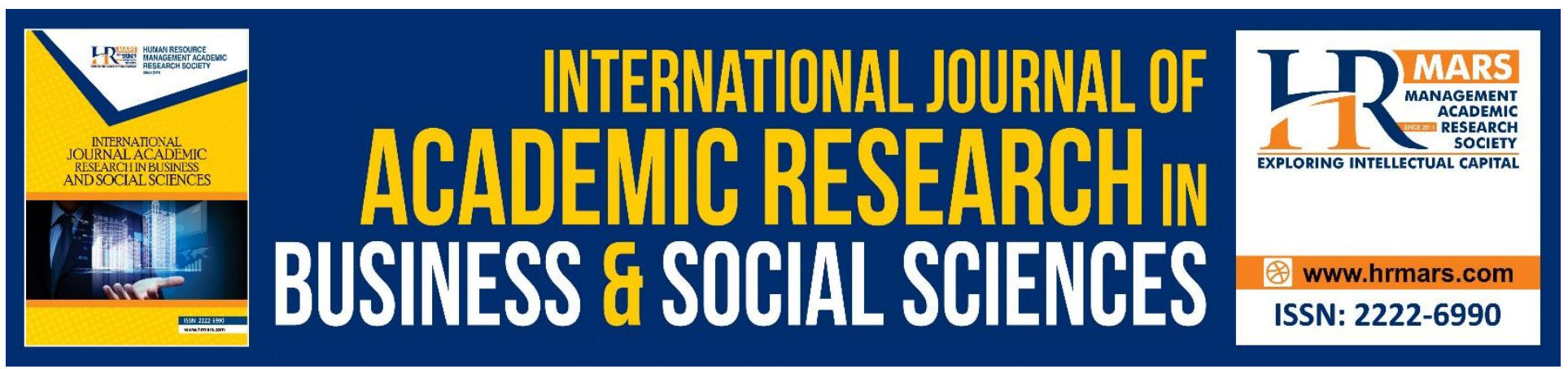

\title{
Experts' View within Fatwa Production in Malaysia
}

\author{
Wan Mohd Khairul Firdaus Wan Khairuldin \\ Faculty of Islamic Contemporary Studies, Universiti Sultan Zainal Abidin, Kampus Gong Badak, \\ Terengganu. \\ Email: wanfirdaus@unisza.edu.my
}

Wan Nur Izzati Wan Nor Anas

Academy of Islamic Studies, University of Malaya, Kuala Lumpur

Abdul Hanis Embong

Centre for Fundamental and Liberal Education, Universiti Malaysia Terengganu, Kuala Lumpur

\begin{abstract}
The problems in sharia laws are not only limited to the aspect of worship. Despite, the problems of sharia laws also include other aspects such as medicine, business interaction, agriculture and others. In the problems of sharia laws, mufti is the most qualified and authorised person to answer any problem of sharia laws. Therefore, mufti generally must be the most knowledgeable individual and well-versed in the principles of Islamic jurisprudence and sharia laws. Nonetheless, mufti is not an expert of all fields. To resolve the problem, this article contains two objectives. First, to explain the appointment method of mufti and sharia committee in Malaysia. Second, to analyse the experts' view in the fatwa decision in Malaysia. Documentation study was done to get data related to the appointment method of mufti and and sharia committee in Malaysia and also the experts' view in the fatwa decision in Malaysia. The findings of the study showed that the appointment method of mufti is not similar with the mufti appointment introduced by majma' fiqh. Second, experts' view plays an important role in fatwa decision when the decided fatwa is related to the fields outside of mufti's and Fatwa Committee's expertise
\end{abstract}

Keywords: Experts, fatwa, Malaysia.

\section{INTRODUCTION}

Generally, fatwa is an explanation or clarification to the problems of sharia laws among the community which appears when there is no explanation or clarification clearly written in al-Quran and al-Sunnah (Buang, 2002). Therefore, explanation and clarification is needed from the knowledgeable people of sharia laws. In this matter, it is clear that mufti is the most qualified person to explain and clarify when there is any confusion and problem among the community. 
There are three resembling definitions related to fatwa. According to al-Qal'ahji (1985), fatwa is defined as an explanation related the problems of religion made by a knowledgeable person. The explanation provided is to answer the confusion posed by the mustafti'. Al-Qasimi (1986) also posed a definition of fatwa which is similar but does not explain further on the knowledge ability in the sharia laws which qualifies for the explanation of sharia laws problems. However, IbnManzur (1956) stated clearly that fatwa is an explanation given by a mufti or knowledgeable person.

Meanwhile, mufti is a person well-versed with sharia laws and given the trust to explain every arising problem as it is not explained in al-Quran and al-Sunnah (Khairuldin, 2016; Ishak, 1981 \& Saedon, 1980).

Today, new problems related to sharia laws rise overwhelmingly among the community. Those problems are not just from the aspect of worship. Indeed, they encompass all other aspects such as finance, agriculture, medicine and others. So, the question is that, what is the appointment method of mufti and sharia committee, and is the expert in a certain field a must in the fatwa decision as the mufti is only an expert in sharia laws only and surely not a knowledgeable person in all fields?

\section{METHODOLOGY}

This article exploited documentation method to get a clear visualisation of experts' view in fatwa decision in Malaysia. Classical and contemporary writings were referred to accomplish data collection for this study.

The result of data collection was then analysed through content analysis method. Content analysis was used to scrutinise and explain the interpretations in the documents. According to Krippendorff (2004:18) and Yusof (2004:34), analysis of content is a research technique by making systematic and objective conclusion through documented data. The result of this analysis

\section{ANALYSIS}

There are scholars who divide mufti into two categories. First, Mufti mustaqil is a mufti that is independent of sects and can produce his own fatwa. Mufti of this category is aperson who is able to understand proofs of sharia laws according to verses of al-quran and al-sunnah. Besides that, he is also able to comprehend ijma' and qiyas. Mufti of this category also masters Arabic language proficiently including balaghah (al-Qasimi, 1986).

The second category is Mufti ghair mustaqil. According to Ibnal-Salah (n.d), Mufti of this category is divided into further four categories. First, mufti who does not follow his sect in understanding the proofs. However, the mufti must possess a strong condition to allow him to perform ijtihad.

Second category, mufti mujtahid. The mufti follows the sect but does not implement the similar methodology as the sect imam in understanding the evidences. Meanwhile, the third one is mufti which is not at the same level with the imam of sect especially in the method of law production 
(istinbat hukum). Even though, the mufti is still eligible in his own ijtihad method. The fourth category is a mufti which can only produce fatwa according to his sect (Khairuldin, 2016). In Malaysia, mufti appointed is the mufti who can produce fatwa according to his sect only except the mufti in Perlis.

This article divides the analysis into two parts. First, the appointment method of mufti and mufti committee in Malaysia. Second, the role of experts in fatwa decision.

\section{First: Appointment method of mufti and mufti committee in Malaysia}

In Malaysia, the decision and production of fatwa is managed by fatwa institution. Fatwa institution is divided into two which are at the state level and national level known as Committee of National Fatwa Council for Islamic Affairs of Malaysia (JFMK).

Fatwa institution at the state level consists of mufti and Fatwa Committee. This means that, mufti in Malaysia cannot produce fatwa alone without Fatwa Committee (Nasohah, 2005). According to Kasan (2001), in spite of that, mufti acts as the chairman in Fatwa Committee. Indeed, based on study Kasan (2001) more, fatwa to be produced will be published by State Islamic Council and the fatwa must go through mufti and Fatwa Committee.

The appointment method of mufti in Malaysia is similar in all states in which the appointment is made by the Sultan. However, there are some states which has State Governor such as Melaka, Federal Territories and Penang, in which the mufti will be appointed by Yang di-Pertuan Agong after consent and suggestion by from State Governor or State Council of Meeting. Such as State of Selangor, according to Enactment of Islam Administration (state of Selangor) (2003), allocated that Sultan must appoint a qualified and suitable person to be the mufti for Selangor. On the other hand, for Melaka as an example, Enactment of Islam Administration (State of Melaka) (2002) allocated that Yang DiPertuan Agong with advice from Chief Minister appoints a qualified and suitable person to be become the Mufti of State Government.

According to Kasan (2001), there is no such specific qualification conditioned for the appointment of mufti in Malaysia. Referring to Hasan (2001) more, this matter could be viewed in Enactment of Islam Administration for each state which does not line somebody's qualification or condition to become mufti. Even though, usually, appointed muftsi in Malaysia are graduates from universities in Middle East such as Egypt and Jordan either at the degree or master level.

Meanwhile, appointment method of Fatwa Committee differs between the states. This can be seen as in Enactment of Islam Administration (Perak) 2004 allocating that Fatwa Committee in Perak consists of mufti, deputy mufti, two members of Committee knowledgeable in sharia laws named by the Council, an officer from Perak Department of Islamic Religion, two to five individuals knowledgeable and well-versed in sharia laws which are appointed by Council and an officer from Department of Mufti appointed by the Council which will become the secretary in Fatwa Committee. 
Furthermore, Fatwa Committee in Kelantan is named as Jamaah Ulama'. Enactment of Islamic Council and Malay Customs of Kelantan (1994), allocated that the membership of Jamaah Ulama' is built upon a mufti, deputy mufti, and the number of Jamaah Ulama' members is eight to five more other members.

In Terengganu, Enactment of Islamic Affairs Administration (Terengganu) 2001, provided that Fatwa Committee stands upon Mufti, deputy mufti, number of members from three to five persons appointed and secretary appointed from officer of Mufti Department.

Meanwhile, in Johor, Enactment of Islamic Administration (State of Johor) 2003, lined that Fatwa Committee are of mufti, deputy mufti of Johor appointed by Sultan with advice from King in State Council of Meeting from among who are qualified and suitable. Besides that, there are two of Council members, two to five of eligible persons appointed by the Council and secretary who is the officer from Mufti Department.

In Pahang, Enactment of Islamic Laws Administration (State of Pahang) 1991 stated that Fatwa Committee of Pahang known as Committee of Sharia Laws Consultants consists of mufti as the chairman, deputy mufti, two of council members appointed by the Council, a person adroit with sharia laws from Pahang Department Islamic Religion and a minimal number of two to six persons appointed by the Council consisting of them who are skilful in sharia laws.

In State of Melaka, there is Enactment of Islamic Religion Administration (State of Melaka) 2002 allocating that Fatwa Committee consists of Mufti appointed by Yang Di Pertuan Agong with advice from Chief Minister from among who are eligible and suitable persons to become mufti. Meanwhile, the members of Melaka Sharia Committee consists of mufti as the chairman, deputy mufti, two of Council members, and at least two individuals and not exceeding seven persons who are suitable and qualified appointed by the Council and secretary from Mufti Department Officer.

In Penang, there is Enactment of Islamic Religion Administration (State of Pulau Pinang) 2004, lining that Fatwa Committee comprises of mufti appointed by Yang Di-Pertuan Agong with advice from State Council of Meeting. Meanwhile, the members of Sharia Committee are formed of Mufti as the chairman, deputy mufti, two officers from Islamic Department of Penang, two from Council and at least two and not more than seven persons from who are expertise in sharia laws appointed by the Council.

In Federal Territories, there is Act of Islamic Laws Administration (Federal Territories) 1993 providing that Fatwa Committee in Federal Territories is named as Committee of Sharia Laws Consultation. This committee is composed of mufti elected by Yang Di Pertuan Agong with advice from Minister after discussion with Islamic Council of Federal Territories from among them who are eligible and suitable to be a mufti, deputy mufti, two Council members, not more than two qualified and appropriate persons appointed by the Council and an officer from Islamic Department of Federal Territories chosen by the council as a secretary. 
Meanwhile, in Perlis, Enactment of Islamic Religion Administration 2006 put that Fatwa Committee is formed of mufti, deputy mufti, six other persons who are Muslims of Sunnah wal Jamaah sect of belief including not more than three Council members and a secretary which is an officer from Mufti Department.

Based on the enactments of states mentioned, there are states that specifically allocate that the appointed members must possess knowledge in sharia laws. According to Hasan Kasnan (2001), the qualifications for the members of Sharia Committee of each state do differ. There are members who are graduates of Islamic studies degree and some are graduates of traditional religious institution (pondok). However, there are members who are from educational background of even a doctorate such as Harun Din who was a member of Perlis Fatwa Committee.

Hence, it is clear that the appointment method of mufti is by getting permission from the sultan of state governor. This means that, no conditioned qualifications to be appointed as a mufti besides getting permission from sultan and governor. Nevertheless, it is a must that the appointed mufti should be a highly-knowledgeable person in religion and sharia laws and not an appointment without scrutinising his background in advance. This also goes to members of Fatwa Committee who are elected in which they should be well-versed with sharia laws and this is explained in several state enactments.

\section{Second: Role of Experts in Fatwa Decision}

The word expert (pakar) derives from Arabic word al-Khabir. According to IbnManzur (1993), expert means an individual knowledgeable in a certain field. There are several opinions of scholars regarding the need of referral to the experts when a problem arises. Among them is According to al-Zayla' $i$ (1982), doctor is a reference for diseases. Indeed according to al-Kasani (1986), when a disease could not be visualised physically, it should be referred to the doctor for the proof. Besides that, referring to al-Nawawi (1991), when there is expert in visualising a thing as damaged, then the object is considered as spoilt. According to scholars' view, it is clear that there is a need to obtain experts' opinion in a certain matter to get a clear understanding.

Problems of Muslim community related to sharia laws are not revolving around certain aspects only. Indeed, it encompasses all fields. In Fatwa committee at the state level, the members are usually appointed from among who are skilful in sharia laws. However, Committee of National Fatwa Council does consists of muftis and elected experts from various fields such as medicine, judiciary, finance and others (http://e-smaf.islam.gov.my, 2018).

When there is an issue arising at the state level and needing of expertise, then experts will be appointed to assist the line-up of State Fatwa Committee to comprehend the issue in more details. However, sometimes the Fatwa Committee will also refer to the produced fatwa published by Committee of National Fatwa Council if the issue has been addressed by Committee of National Fatwa Council. According to Rusli (2018), Fatwa Committee of Federal Territories sought opinion from 
medical experts when there was an issue of inhaler consumption during month of Ramadhan by asthmatic patients.

At the national level, even though Committee of National Fatwa Council already has a line-up of experts in various fields, but when there is a need of other experts, the experts will be appointed (Khairuldin et al., 2018). This is to comprehend the problem and it is in need of expert before a fatwa is decided. Referring to Subri dan Zulkiple (2016), Fatwa Committee had already sought experts' view on vape. This is due arising issue on law of vape inhalation.

\section{CONCLUSION}

Experts' view is crucial to solve a law problem. This is due to the fact that deep comprehension in certain problem will ease the fatwa institutions which are Fatwa Committee and Malaysia Committee of Fatwa Council to resolve a certain problem properly. The produced fatwa after getting experts' opinion is seen as the fatwa institution does not merely produce a fatwa without apprehending the issue of a certain problem deeply.

\section{ACKNOWLEDGEMENT}

This paper is founded on the research project of the Special Research Grant Scheme (SRGS)UniSZA/2017/SRGS/07. Special appreciation is owed RMIC Universiti Sultan Zainal Abidin (UniSZA) for sponsoring and supporting this research.

\section{REFERENCES}

Akta Pentadbiran Undang-Undang Islam (Wilayah-wilayah Persekutuan)1993

Al-Kasani, A.B. (1986). Bada'i al-Sana'i fi Tartib al-Shara'i. Beirut: Dar al-Kutub al-Ilmiyyah.

Al-Nawawi, Y. (1991). Rawdat at-Talibin wa 'Umdat al-Muftin. Beirut: Al-Maktab Al-Islami.

al-Qasimi, J. (1986). Kitab al-Fatwa fi al-Islam. Beirut: Dar al-Kutub al-'Ilmi.

Al-Zayla'i, F. (1892). Tabyin al-Haqa'iq Sharh Kanz al-Daqa'iq. Kaherah: al-Matba' ah Al-Kubra AlAmiriyyah.

Buang, A.H. (2002), Analisis Fatwa-Fatwa Semasa di Malaysia, Jurnal Syariah, 10(1).

Enakmen Majlis Agama Islam dan Adat Istiadat Melayu( Kelantana)1994

Enakmen Pentadbiran Agama Islam (2006)

Enakmen Pentadbiran Agama Islam (Negeri Johor) 2003

Enakmen Pentadbiran Agama Islam (Negeri Melaka) 2002 
INTERNATIONAL JOURNAL OF ACADEMIC RESEARCH IN BUSINESS AND SOCIAL SCIENCES

Vol. 8, No. 11, Nov, 2018, E-ISSN: 2222-6990 (C) 2018 HRMARS

Enakmen Pentadbiran Agama Islam (Negeri Perak) 2004

Enakmen Pentadbiran Agama Islam (Negeri Pulau Pinang)2004

Enakmen Pentadbiran Agama Islam (Negeri Selangor) 2003

Enakmen Pentadbiran Hal Ehwal Agama Islam (Terengganu)2001

Ibnal-Salah (n.d.), Fatwa wa al-Masalil fi al-Tafsir wa al-mufti wa al-mustafi, Beirut: Dar al-Kutub alArabiyyah.

IbnManzur. (1956). Lisan al-Arab. Beirut: Dar al-Beirut.

Ishak, O. (1981). Fatwa dalam perundangan Islam. Shah Alam: Fajar Bakti.

Kasan, H. (2001), Institusi Fatwa dalam Perundangan Negara: Satu Penilaian menurut Siasah Syar'iyyah, Jurnal Pengajian Umum, 2(2001): 37-63.

Khairuldin, W. M. K. F. W., Embong, A. H., Anas, W. N. I. W. N., Mohd, H., \& Ismail, D. The Application Of Technology In The Dissemination Of Fatwas: A Study On Religious Institutions In Malaysia. International Journal of Civil Engineering and Technology, 9(7), 2018, pp. 1590-1596.

Khairuldin, W.M.K.F.W. (2016). Konsep Fatwa dalam Islam. Kuala Terengganu: Penerbit UniSZA.

Khairuldin, W.M.K.F.W., Ismail, D., Anas, W.N.I.W.N., Ibrahim, I., \& Fauzi, N. (2016). Freedom of Speeches by Mufti According to Islam: Implication to Fatwa in Malaysia. International Journal of Academic Research in Business and Social Sciences. 6 (12). Pp 141-151.

Krippendorff, K. (2004). Content Analysis: An Introduction to Its Methodology. California: SAGE Publications Ltd.

Nasohah, Z. (2005). Undang-undang Penguatkuasaan Fatwa di Malaysia. ISLAMIYYAT, 27(1). pp 2544.

Othman, M.S. (1980, 15 Mac). Tuan Haji Ahmad bin Mohd. Said: Pemimpin al-Tarikat al-Ahmadiyyah al-Rashidiyyah al-Dandarawiyyah, Proceeding Seminar 'Majlis Memperingati Tokoh Ulama Silam yang ke-V'. Fakulti Pengajian Islam, Universiti Kebangsaan Malaysia, Bangi, Selangor. (pp. 17-43).

Qalahaji, M.R. (1985). Mu'jam Lughat al-Fuqaha. Beirut: Dar al-Nafais 
INTERNATIONAL JOURNAL OF ACADEMIC RESEARCH IN BUSINESS AND SOCIAL SCIENCES Vol. 8, No. 11, Nov, 2018, E-ISSN: 2222-6990 @ 2018 HRMARS

Yusof, R. (2004). Penyelidikan Sains Sosial. Kuala Lumpur: PTS Publications \& Distributors. 